\title{
HUBUNGAN KARAKTERISTIK SOSIAL EKONOMI RUMAH TANGGA DENGAN PEMENUHAN HAK ANAK DI WILAYAH DAMPINGAN PLAN INTERNATIONAL INDONESIA PROGRAM UNIT SIKKA, NUSA TENGGARA TIMUR
}

\author{
Relationship between Household Social Economic Characteristics and Children's \\ Rights Fulfillment, at Plan International Indonesia Program Unit Sikka, \\ Nusa Tenggara Timur
}

DWI HASTUTI ${ }^{1 *}$, KASIANUS SEBHO ${ }^{2}$, YOSEF LEGA LAMAWURAN ${ }^{2}$
${ }^{1}$ Departemen IImu Keluarga dan Konsumen, Fakultas Ekologi Manusia, Institut Pertanian Bogor, Jalan Lingkar Kampus IPB Dramaga, Bogor 16680
${ }^{2}$ Staf PLAN International Indonesia, Program Unit Sikka, Nusa Tenggara Timur

\begin{abstract}
The study was conducted at PLAN's area in District of Sikka, East Nusa Tenggara Province. There were five villages at Sub-district of Magepanda selected as location of the study which were Desa Magepanda, Desa Kolisia B, Desa Kolisia, Desa Done, dan Desa Reroroja. All households with children ages 0-18 years in those villages were chosen as samples of the study for a total of 2626 households. This report was analysed using a secondary data collected by Plan International Indonesia PU Sikka. Based on secondary data, then a descriptive statistics using frequency distribution was applied, while inferential statistics were applied using $t$-student analysis and Spearman rank correlation analysis. Results showed that more than half of samples (53\%) were classified as low in term of socio economic status. The study found that $75,6 \%$ of children have no birth certificate; $58,4 \%$ have no involvement at all on civil voices regarding child's issue at village level; and only $36,7 \%$ of children living at home with flush toilet. In terms of health, it was found that more than 55 percent of children received medication, immunization and exlussive breast feeding, which describe as adequate health accesses and practices. With regards to child's right for leissure activities, it showed that only $29,4 \%$ of under five years old children played and supervised, the rest played alone and unsupervised. In educational needs results showed that only $10 \%$ of children attended to early childhood education program (PAUD), and among samples with ages 7-18 years old, there was 16,7\% have no education, and only 10\% of those children attended to high school. However, more than half of the households $(51,4 \%)$ considered as moderate for their child's right fulfillement. Statistical analysis showed differences among villages in fulfilling to child's right. Meanwhile, there were significant and positive relationships between socio economic status and child right's fulfillment, which means that the better the socio economic status of the family is the better the child's right fulfillment.
\end{abstract}

\section{Key words: child's right fulfillment, household's socio economic characteristic}

\section{PENDAHULUAN}

Usaha untuk meningkatkan taraf hidup dan kesejahteraan rakyat Indonesia merupakan tujuan utama pembangunan nasional. Upaya peningkatan kesejahteraan ini meliputi seluruh golongan masyarakat, termasuk kesejahteraan anak. Dalam pembangunan nasional, anak merupakan sumber potensi bangsa serta penerus cita-cita bangsa, untuk itu anak perlu mendapatkan kesempatan yang besar untuk tumbuh dan berkembang secara wajar, baik rohani, jasmani, maupun sosial.

Laporan Indikator Kesejahteraan Anak (BPS 2000) menunjukkan bahwa masalah kesejahteraan anak selalu berkaitan erat dengan masalah kependudukan, yakni menyangkut pertumbuhan penduduk yang tinggi. Tingkat pertumbuhan penduduk yang tinggi secara langsung menambah jumlah penduduk usia muda. Selain itu, persoalan kepadatan penduduk juga berkaitan dengan kesejahteraan penduduk. Masalah sosial 
yang sering timbul karena padatnya penduduk di suatu wilayah merupakan indikasi bahwa persoalan kepadatan penduduk mempunyai pengaruh pada perbaikan tingkat kesejahteraan, terutama anak-anak.

Masalah menonjol lainnya adalah kemiskinan struktural. Di wilayah NTT seperti Kabupaten Lembata kemiskinan dan ketiadaan pekerjaan mendorong keluarga ke luar provinsi, atau ke luar negeri untuk mencari nafkah (Martianto et al. 2006). Pada keluarga lain di Kabupaten Timor Tengah Utara, terutama saat paceklik dan musim kering, pemenuhan kebutuhan keluarga dilakukan dengan melakukan pinjaman ke warung, saudara, menjual ternak, pergi ke kota mencari pekerjaan lain, dan sebagainya (Martianto et al. 2007). Di NTT pada umumnya ibu juga bekerja, dan membantu suami di ladang dan kebun, bercocok tanam, memelihara tanaman, membersihkan gulma, memanen, dan lain-lain. Kepergian ibu ke ladang, membawa dampak kepada pola asuh anak, dan kebutuhan pemeliharaan dan peng-awasan anak diserahkan kepada anggota keluarga lain seperti nenek, bibi atau kakak kandungnya yang lebih besar (Martianto et al. 2007; Martianto et al. 2008). Hal ini berdampak pada berubahnya pola pengasuhan keluarga yang dapat merugikan tumbuh kembang anak karena pengasuhan makan, kesehatan, gizi, dan pendidikan diserahkan kepada orang lain yang boleh jadi tidak sesuai dengan kebutuhan anak.

Sesuai dengan ketentuan hak asasi manusia, masa anak membutuhkan kasih sayang yang utuh, bimbingan, dan perlindungan dari orangtua. Namun, dalam kenyataannya di masyarakat sangat banyak peristiwa yang menimpa anak-anak sehingga merenggut masa kecilnya dan bahkan masa depannya. Tidak banyak pula pihak yang turut memikirkan dan melakukan langkahlangkah konkret dalam hal perlindungan hak anak. Hal ini dapat dilihat di sebagian besar wilayah Indonesia dengan adanya praktek eksploitasi terhadap anak yang dijadikan pengemis, pengamen jalanan, pekerja anak, pekerja seks komersial, diperdagangkan, dan sebagainya (Najih 2003). Di perdesaan bentuk pengabaian hak anak dapat dilihat dalam bentuk kurangnya konsumsi makan, pemeliharaan kesehatan dan gizi anak tak memadai, dan pemberian pendidikan yang minimal karena terkait kemiskinan keluarga dan kemiskinan struktural di daerah tinggalnya. Oleh karena itu, penelitian ini dilakukan untuk mengetahui kondisi sosial ekonomi keluarga dan kaitannya dengan pemenuhan hak anak dalam rangka memperbaiki kehidupan anak di wilayah dampingan PLAN di Sikka, mengingat mereka berada pada situasi kemiskinan dan kurang gizi.

Tujuan penelitian ini adalah mengetahui hubungan karakteristik sosial ekonomi rumah tangga dan pemenuhan hak anak di wilayah dampingan Plan Internasional Indonesia Program Unit Sikka, Nusa Tenggara Timur.

\section{METODE}

\section{Desain, Lokasi, dan Waktu}

Desain yang digunakan pada penelitian ini adalah cross sectional study. Pengumpulan data dilakukan pada bulan Juli sampai dengan bulan Desember 2008. Penelitian dilakukan di lima desa, yaitu Desa Magepanda, Desa Kolisia B, Desa Kolisia, Desa Done, dan Desa Reroroja, Kecamatan Magepanda, Kabupaten Sikka.

\section{Teknik Penarikan Contoh}

Penelitian ini merupakan data sekunder yang bersumber dari pengumpulan data $\mathrm{PU}$ Sikka. Populasi pada penelitian ini adalah seluruh keluarga yang tinggal di desa terpilih, dan jumlah keluarga yang menjadi sampel penelitian ini adalah 2626 kepala keluarga (KK), dengan rincian di Magepanda $722 \mathrm{KK}$; Kolisia B 313 KK; Kolisia 547 KK; Done 361 KK dan Reroroja 683 KK.

\section{Pengolahan dan Analisis Data}

Berbagai data yang dikumpulkan, digali melalui wawancara dengan menggunakan kuesioner terstruktur. Selanjutnya, data yang terkumpul dianalisis dengan statistik deskriptif dan inferensia. Data deskriptif disajikan dalam bentuk grafik dan tabel distribusi frekuensi. Data dianalisis dengan menggunakan uji beda t-student untuk melihat perbedaan peubah antar lokasi, sedangkan analisis korelasi Rank Spearman digunakan untuk menentukan hubungan antara karakteristik sosial ekonomi rumah tangga dan pemenuhan hak anak. Untuk pelaporan penelitian ini data yang sudah tersedia kemudian dikelompokkan menjadi data pemenuhan hak anak, yang diolah dengan memberikan rangking pada pemenuhan hak anaknya, apakah lima rumpun hak anak sudah terpenuhi atau belum oleh keluarga yaitu hak sipil dan kebebasan, hak pengasuhan keluarga dan perawatan alternatif, hak kesehatan dan 
kesejahteraan, hak pendidikan, serta hak waktu luang dan kegiatan budaya.

\section{HASIL DAN PEMBAHASAN}

\section{Karakteristik Sosial Ekonomi Rumah Tangga}

Lebih dari separuh kepala keluarga (KK) di daerah penelitian memiliki pekerjaan sebagai petani $(63,4 \%)$ tanaman pangan. Para petani tersebut disamping mempunyai aktivitas pertanian tanaman pangan dan tanaman tahunan juga aktivitas nonpertanian dari peternakan dan jasa formal (buruh) maupun nonformal (tukang ojek dan pedagang).

Aset tidak produktif yang dimiliki masyarakat di daerah penelitian umumnya meliputi sawah, kolam, dan tanaman umur panjang, sedangkan aset produktif bergerak berupa hewan ternak serta kendaraan bermotor (sepeda motor) dan tidak bermotor (sepeda). Dari Tabel 1 diketahui bahwa hanya $26 \%$ rumah tangga sampel yang menyatakan memiliki aset tidak produktif tersebut.

Pada umumnya reponden memiliki penghasilan rumah tangga kurang dari Rp 250.000 per bulan (84,4\%) dan memiliki lahan $(84,1 \%)$. Dalam hal keamanan keuangan, hanya sekitar $35 \%$ rumah tangga yang memiliki tabungan, dan sebanyak $65,6 \%$ responden menyatakan bahwa rumah tangga tidak memiliki tabungan (Tabel 1). Namun demikian besarnya tabungan tidak dikumpulkan dalam data penelitian ini.

Dilihat dari karakteristik sosial ekonominya terdapat perbedaan nyata keragaman pemilikan aset yang dinyatakan dalam rataan skor antar desa $(p<0,01)$. Masyarakat Desa Done dari aspek karakteristik sosial ekonomi adalah yang terendah. Dibandingkan dengan desa-desa lain di Kecamatan Magepanda, Desa Done memiliki akses yang lebih sulit dibandingkan dengan desa yang lainnya, dengan kehidupan sepenuhnya tergantung dengan pertanian. Lokasi desa lebih jauh dari jalan raya umum dan lebih sulit dijangkau sehingga berdampak pada akses informasi dan pasar yang juga lebih sulit. Dibandingkan dengan lainnya, Desa Reroroja memiliki karakteristik sosial ekonomi lebih baik, akses masyarakat terhadap pasar dan informasi juga lebih mudah dibandingkan desa lain. Selain itu masyarakat Desa Reroroja adalah masyarakat yang dari aspek sosial budayanya lebih majemuk dengan keragaman lapangan pekerjaan yang lebih beraneka ragam antara lain pertanian, perdagangan, dan juga nelayan.

Jika dihitung dari rata-rata skor kepemilikan aset, kemudian kondisi sosial ekonomi rumah tangga dibagi menjadi tiga kategori, yaitu kurang, cukup, dan baik (Gambar 1), maka terlihat bahwa lebih dari $50 \%$ responden memiliki situasi sosial ekonomi kurang $(53 \%)$, dengan skor rata-rata 7,0 (skor total 11). Tampak pula bahwa Desa Magepanda memiliki rumah tangga dengan proporsi tertinggi pada kategori sosial ekonomi baik, sebaliknya Desa Done memiliki proporsi terendah $(10,8 \%)$. Dengan kondisi demikian rumah tangga di Desa Done adalah paling lemah dalam hal ekonomi.

Tabel 1. Sebaran responden berdasarkan situasi sosial ekonomi rumah tangga

\begin{tabular}{|c|c|c|c|c|c|c|}
\hline \multirow{2}{*}{ Sosek } & \multicolumn{6}{|c|}{ Desa (\%) } \\
\hline & Magepanda & Kolisia b & Kolisia & Done & Reroroja & Total \\
\hline \multicolumn{7}{|c|}{ Penghasilan keluarga per bulan } \\
\hline$\leq 250.000$ & 85,9 & 70,7 & 87,1 & 89,9 & 85,6 & 84,4 \\
\hline $251.000-500.000$ & 8,0 & 12,5 & 7,1 & 4,7 & 1,8 & 6,1 \\
\hline$>500.000$ & 6,0 & 16,8 & 5,8 & 5,3 & 12,6 & 9,5 \\
\hline \multicolumn{7}{|c|}{ Keluarga memiliki tabungan } \\
\hline Ya & 34,7 & 49,8 & 38,4 & 14,6 & 33,5 & 34,4 \\
\hline Tidak & 65,3 & 50,2 & 61,6 & 85,4 & 66,5 & 65,6 \\
\hline \multicolumn{7}{|c|}{ Keluarga memiliki usaha sampingan } \\
\hline Ya & 57,0 & 62,1 & 39,0 & 29,8 & 77,8 & 54,8 \\
\hline Tidak & 43,0 & 37,9 & 61,0 & 70,2 & 22,2 & 45,2 \\
\hline \multicolumn{7}{|c|}{ Keluarga memiliki lahan } \\
\hline Ya & 85,3 & 93,6 & 70,7 & 95,8 & 83,0 & 84,1 \\
\hline Tidak & 14,7 & 6,4 & 29,3 & 4,2 & 17,0 & 15,9 \\
\hline \multicolumn{7}{|c|}{ Keluarga memiliki barang berharga } \\
\hline Ya & 35,5 & 28,4 & 22,9 & 28,0 & 16,3 & 26,0 \\
\hline Tidak & 64,5 & 71,6 & 77,1 & 72,0 & 83,7 & 74,0 \\
\hline
\end{tabular}




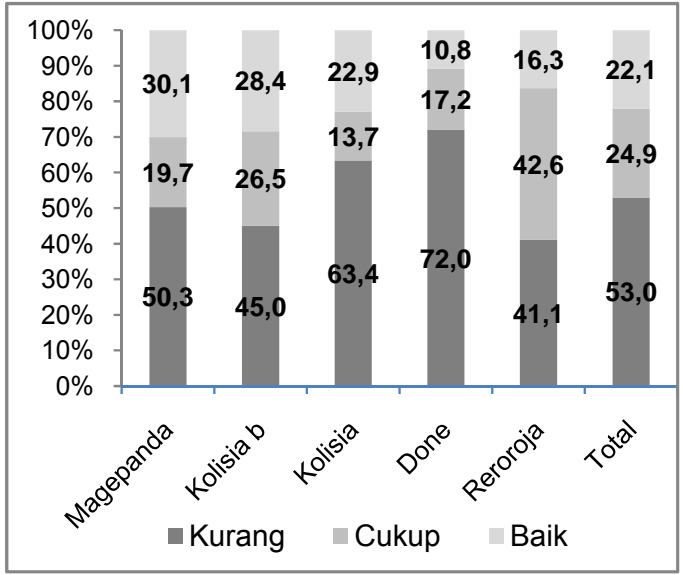

Gambar 1. Sebaran karakteristik sosial ekonomi rumah tangga

\section{Pemenuhan Hak Anak}

Bangsa Indonesia sudah selayaknya memberikan perhatian lebih terhadap perlindungan dan dukungan dalam memenuhi kebutuhan hak-hak anak dengan mengacu pada Konvensi Hak Anak, UUD 1945 dan GBHN. Pertumbuhan ekonomi nasional, yang diikuti dengan peningkatan kesejahteraan penduduk serta stabilitas nasional yang semakin mapan, juga dapat membantu tugas-tugas negara untuk melindungi anakanak dari segala bentuk perlakuan salah, penelantaran, eksploitasi, diskriminasi, dan situasi-situasi yang membahayakan hidup anak.

Anak merupakan sasaran utama pembangunan, sehingga diarahkan pada investasi sumberdaya manusia (human invesment). Kesejahteraan anak dipandang sebagai suatu keharusan, oleh karenanya semua pihak akan merasa berkepentingan untuk melakukan perlindungan kepada anak.

Hak Sipil dan Kebebasan. Berdasarkan Konvensi Hak Anak (KHA), hak sipil dan kebebasan anak yang paling utama adalah kepemilikan identitas. Semua anak harus diberi kesempatan untuk menemukan jati diri (Depsos 2000). Informasi tentang identitas anak dapat diperoleh dari akte kelahiran. Namun, dalam kenyataannya pencatatan kelahiran di Indonesia masih sangat terbatas, khususnya di wilayah terpencil. Selain itu, pencatatan kelahiran juga dirasakan masih relatif mahal. Sebagai akibatnya, pencatatan kelahiran menjadi kurang membudaya.

UNICEF (1998) melaporkan bahwa Indonesia merupakan salah satu negara yang mempunyai tingkat pencatatan kelahiran terendah. Tingkat kelahiran tercatat di Indonesia berkisar antara $50-69 \%$. Di tahun yang sama, PLAN Internasional bekerjasama dengan NGO Committee on UNICEF melakukan analisis situasi mengenai unregistered children di 3 negara di Asia Tenggara termasuk Indonesia. Hasil survei menunjukkan bahwa hanya kurang dari $30 \%$ sampel di wilayah dampingan PLANInternasional di Indonesia yang tercatat kelahirannya.

Dari penelitian ini terlihat bahwa hampir dua pertiga anak $(75,6 \%)$ di desa penelitian belum memiliki akte kelahiran (Tabel 2). Kelemahan pencatatan kelahiran diduga berakibat pada rentannya pelanggaran terhadap hak anak. Anak yang tidak memiliki akte kelahiran tidak terlindungi secara hukum sebagaimana diatur dalam pasal 53 ayat 2 tentang hak anak atas suatu nama dan status kewarganegaraan dan pasal 56 ayat 1 tentang hak anak untuk mengetahui dan sejauh mungkin diasuh oleh kedua orangtuanya.

Rendahnya cakupan kepemilikan akte kelahiran dalam penelitian ini karena sampel dalam penelitian ini mencakup seluruh anak berusia 0-18 tahun. Jika cakupan kepemilikan akte kelahiran anak dibatasi untuk anak di bawah 5 tahun, maka diduga angka cakupan kepemilikan akte pada umumnya cukup tinggi. Hal ini berkaitan dengan adanya keputusan Bupati No 93 Tahun 2004 tentang penyederhanaan prosedur pengurusan akte kelahiran bagi anak. Namun data untuk kepemilikan akte menurut kelompok umur tak tersedia.

Tabel 2. Sebaran anak berdasarkan kepemilikan akte kelahiran

\begin{tabular}{lcccccc}
\hline Kepemilikan & \multicolumn{7}{c}{ Desa (\%) } \\
\cline { 2 - 6 } Akte Kelahiran & Magepanda & Kolisia b & Kolisia & Done & Reroroja & Total \\
\hline Ya & 31,7 & 21,9 & 19,7 & 45,7 & 8,9 & 24,4 \\
Tidak & 68,3 & 75,1 & 80,3 & 54,3 & 91,1 & 75,6 \\
\hline
\end{tabular}


Dibandingkan antar desa, maka kepemilikan akte anak di Desa Reroroja paling rendah $(8,9 \%)$, sebaliknya di Desa Done paling tinggi (45,7\%). Rendahnya cakupan kepemilikan akte kelahiran anak di Desa Reroroja disebabkan karena masyarakat Desa Reroroja sebagai masyarakat majemuk memiliki tingkat migrasi yang tinggi.Hal ini bisa juga berhubungan dengan adanya kebijakan yang berbeda di tiap desa terkait dengan kepemilikan akte kelahiran, atau karena adanya dukungan dari tokoh, dan lain-lain.

Dalam hak sipil dan kebebasan juga terkandung hak kebebasan berserikat bagi anak. Namun hak ini lebih banyak terkait dengan peran pemerintah desa dan bukan rumah tangga atau keluarga, mengingat pertemuan dikoordinasikan di tingkat desa. Peran keluarga atau rumah tangga hanya memberikan kesempatan kepada anak untuk berpartisipasi. Jika ditelusur pertemuan untuk kepentingan anak cukup luas, misalnya masalah kesehatan dan gizi anak, yang biasanya disampaikan oleh tenaga kesehatan tingkat desa seperti bidan desa, kader PKK dan Posyandu, atau masalah pendidikan anak (usia dini hingga remaja) yang dapat diungkapkan oleh guru PAUD, kader atau tutor PAUD, guru, dan kepala sekolah tingkat TK, SD, SMP hingga SMA. Tabel 3 menunjukkan bahwa sebagian besar $(62 \%)$ responden menyatakan bahwa di desa terdapat pertemuan-pertemuan yang dilakukan untuk membahas kepentingan anak, semisal pertemuan terkait kesenian yang melibatkan anak. Namun, keluarga atau rumah tangga sampel menyatakan bahwa dalam pertemuan tersebut anak masih jarang dilibatkan. Hal ini terlihat dari persentase tertinggi di seluruh desa $(58,4 \%)$ yang me- nyatakan bahwa anak tidak pernah mengikuti pertemuan.

Hak Pengasuhan Keluarga dan Perawatan Alternatif. Hasil Susenas tahun 2000 menunjukkan bahwa persentase wanita yang statusnya belum kawin di daerah perkotaan lebih tinggi $(92,8 \%)$ dibandingkan daerah perdesaan $(85,2 \%)$. Di daerah perdesaan, adanya kultur menikah di usia muda menyebabkan persentase perempuan yang kawin lebih tinggi dibandingkan di daerah perkotaan.

Usia yang terlalu dini dalam memasuki perkawinan, berdampak cukup luas terhadap perkembangan si ibu maupun si anak. Semakin muda seseorang melakukan perkawinan pertama, akan menyebabkan semakin panjang umur masa reproduksinya. Hal ini akan berpengaruh pula pada makin besarnya kemungkinan pasangan tersebut untuk memiliki atau melahirkan anak.

Tabel 4 menunjukkan bahwa sebagian besar $(63,2 \%)$ responden memiliki anggota keluarga $\leq 4$ orang, sisanya 5-7 orang $(33,1 \%)$ dan $\geq 8$ orang $(3,7 \%)$. Berdasarkan kategori BKKBN (1998), maka keluarga dengan anggota kurang dari 4 orang termasuk kategori keluarga kecil, yang kemudian dikenal sebagai Norma Keluarga Kecil Bahagia Sejahtera (NKKBS). Kesejahteraan anak yang tinggal pada keluarga kecil relatif akan lebih terjamin dibandingkan keluarga besar, sebaliknya semakin banyak jumlah anggota keluarga pemenuhan kebutuhan keluarga cenderung lebih sulit, termasuk dalam pemenuhan kebutuhan pangan dan gizi keluarga (Hastuti 1989). Dengan rata-rata besar keluarga yang sebagian besar berjumlah 4 orang, maka dikatakan bahwa hak anak di wilayah penelitian di Sikka dalam pemenuhan hak pengasuhan dan perawatan anak cukup memadai.

Tabel 3. Sebaran anak berdasarkan hak partisipasi

\begin{tabular}{lccccrr}
\hline \multirow{2}{*}{ Pendidikan } & \multicolumn{5}{c}{ Desa (\%) } \\
\cline { 2 - 7 } & Magepanda & Kolisia b & Kolisia & Done & Reroroja & Total \\
\hline Ada pertemuan untuk kepentingan anak & & & & & \\
Ya & 59,4 & 17,4 & 76,7 & 19,8 & 87,2 & 62,0 \\
Tidak & 40,6 & 82,6 & 23,3 & 80,2 & 12,8 & 38,0 \\
\hline Anak dilibatkan dalam pertemuan & 0,4 & 1,1 & 14,1 & 0,0 & 1,3 & 3,2 \\
Sering & 1,1 & 19,6 & 39,9 & 0,4 & 92,9 & 38,4 \\
Kadang-kadang & 98,5 & 79,3 & 46,0 & 99,6 & 5,8 & 58,4 \\
\hline Tidak pernah & & & & & & \\
\hline
\end{tabular}


Tabel 4. Sebaran anak berdasarkan jumlah anggota keluarga

\begin{tabular}{|c|c|c|c|c|c|c|}
\hline \multirow{2}{*}{$\begin{array}{c}\text { Jumlah Anggota } \\
\text { Keluarga }\end{array}$} & \multicolumn{6}{|c|}{ Desa (\%) } \\
\hline & Magepanda & Kolisia b & Kolisia & Done & Reroroja & Total \\
\hline$\leq 4$ orang & 62,3 & 66,6 & 61,9 & 71,9 & 59,0 & 63,2 \\
\hline 5-7 orang & 34,1 & 30,9 & 33,3 & 26,1 & 36,5 & 33,1 \\
\hline$\geq 8$ orang & 3,6 & 2,5 & 4,8 & 1,9 & 4,5 & 3,7 \\
\hline
\end{tabular}

Hak Kesehatan dan Kesejahteraan. Anak merupakan kelompok penduduk yang paling rentan terhadap gangguan kesehatan dan gizi. Pemberian dan konsumsi makanan, status kesehatan ibu, status kesehatan bayi saat lahir dan pelayanan kesehatan merupakan faktor penting dalam peningkatan kesehatan dan status gizi anak. Gangguan terhadap faktor-faktor ini akan diikuti pula dengan gangguan terhadap kesehatan dan gizi anak.

Tinggi rendahnya angka kematian bayi dipengaruhi oleh penolong persalinan, pemberian ASI dan makanan, pemberian imunisasi serta vitamin A. Kenyataannya, persalinan sekitar $50 \%$ ibu di desa penelitian belum ditolong oleh tenaga medis. Dengan penempatan tenaga bidan di desa-desa diharapkan persalinan oleh tenaga medis terlatih dapat meningkat. Semakin tingginya persalinan yang ditolong oleh tenaga medis diharapkan dapat menekan angka kematian ibu dan bayi.

Kesehatan dan gizi pada masa anakanak menentukan banyak aspek kehidupan, termasuk kesehatan, intelektualitas, prestasi dan produktivitasnya pada masa remaja dan dewasa. Untuk mendapatkan anak yang sehat dan bertumbuh kembang baik, ibu harus mengkonsumsi makanan bergizi selama menyusui. Air Susu Ibu (ASI) merupakan makanan paling baik bagi bayi, karena ASI mengandung zat penolak/pencegah penyakit serta menjadi sarana menjalin hubungan kasih sayang antara ibu dan anak. Hasil penelitian menunjukkan bahwa sekitar $55,8 \%$ anak sudah memperoleh ASI eksklusif (Tabel 5).
Pemanfaatan fasilitas kesehatan di desa sudah cukup baik, yakni mencapai $90 \%$. Sebagian besar ibu menyatakan sering membawa anak ke posyandu $(80,5 \%)$. Namun, tingginya pemanfaatan fasilitas kesehatan tersebut ternyata tidak diikuti dengan keaktifan ibu memberikan imunisasi dan vitamin A kepada anak. Anak balita di daerah penelitian yang mendapat imunisasi BCG, DPT, Polio, dan Campak masih jauh dibawah $70 \%$. Sementara anak balita yang memperoleh vitamin A minimal dua kali dalam setahun hanya sekitar $60 \%$ (Tabel 5). Padahal imunisasi penting dalam memberikan kekebalan kepada anak sejak dini yang dapat memberikan perlindungan atau antibodi kepada tubuh terhadap beberapa penyakit yang membahayakan.

Penelitian ini untuk semua KK dan mencakup keluarga yang memiliki anak usia 0-18 tahun. Sedangkan cakupan pemenuhan hak anak di aspek kesehatan sebenarnya cukup tinggi dengan adanya perhatian pemerintah dan semua stakeholder kesehatan yang pada akhir-akhir ini digalakkan, seperti desa siaga, dan program "ASI POI" untuk kampanye ASI Eksklusif. Dalam bahasa lokal Sikka, ASI POI artinya adalah ASI saja. Pada masyarakat desa Magepanda akses anak untuk aspek kesehatan lebih tinggi dibandingkan dengan desa lainnya karena merupakan ibu kota kecamatan dan karenanya akses informasi di bidang kesehatan yang cukup baik berdampak pada tingkat kesadaran masyarakat akan aspek kesehatan cukup tinggi pula.

Tabel 5. Sebaran anak berdasarkan hak kesehatan

\begin{tabular}{lcccccc}
\hline \multicolumn{1}{c}{ Kesehatan* $^{*}$} & \multicolumn{5}{c}{ Desa (\%) } \\
\cline { 2 - 6 } & Magepanda & Kolisia b & Kolisia & Done & Reroroja & Total \\
\hline Anak lahir ditolong tenaga medis & 63,3 & 51,1 & 57,8 & 58,4 & 45,5 & 55,4 \\
Anak memproleh ASI eksklusif selama 6 bulan & 76,0 & 46,3 & 39,5 & 52,6 & 53,3 & 55,8 \\
Anak diimunisasi : & & & & & & \\
BCG & 84,9 & 49,2 & 56,1 & 56,0 & 54,6 & 62,7 \\
DPT & 84,2 & 48,2 & 56,3 & 54,8 & 54,2 & 62,3 \\
Polio & 83,7 & 48,2 & 55,8 & 54,6 & 55,6 & 62,3 \\
Campak & 81,4 & 45,7 & 52,1 & 54,3 & 52,4 & 59,8 \\
Anak dapat vitamin A 2x setahun & 83,0 & 48,2 & 53,7 & 50,7 & 52,9 & 60,5 \\
\hline
\end{tabular}


Proses tumbuh kembang anak sedikit banyak juga dipengaruhi oleh kualitas lingkungan tempat tinggal, meliputi lingkungan fisik dan nonfisik. Kepemilikan tempat tinggal merupakan indikator awal dalam menentukan tingkat kesejahteraan atau kemapanan sebuah rumah tangga. Rumah tangga yang memiliki tempat tinggal sendiri relatif lebih mapan dibandingkan rumah tangga yang belum/tidak memiliki tempat tinggal sendiri. Fenomena lain yang tampak adalah adanya kecenderungan rumah tangga dengan tempat tinggal bukan milik sendiri untuk selalu berpindah tempat. Dampak yang semakin besar akan dirasakan apabila perpindahan tempat tinggal itu juga harus diikuti oleh pindahnya tempat bersekolah. Hal ini akan mempengaruhi proses belajar anak.

Selain status kepemilikan tempat tinggal, indikator lain yang dapat digunakan untuk menentukan tingkat kesejahteraan rumah tangga adalah fasilitas tempat tinggal. Lebih dari separuh $(53,1 \%)$ responden memiliki ventilasi yang kurang memadai, sehingga sirkulasi udara dalam rumah kurang terjamin. Hal ini menunjukkan tingginya risiko ISPA karena debu dan ruang yang lembab.

Keadaan lingkungan fisik dan sanitasi di sekitar rumah sangat mempengaruhi kesehatan penghuni rumah tersebut. Hampir seluruh $(96,7 \%)$ anak dapat mengakses sumber air bersih dengan mudah. Sumber air tersebut berasal dari sumur umum $(59,8 \%)$. Ketersediaan air bagi masyarakat di Kecamatan Magepanda pada dasarnya mencukupi untuk kebutuhan sehari-hari. Namun dari segi aspek kelayakan sebenarnya cukup memprihatinkan antara lain karena untuk masyarakat pesisir, kecuali Desa Done, sumber air bersihnya dari sumur yang berdasarkan hasil uji kelayakan mengandung banyak bakteri E-coli. Bahkan bagi masyarakat Desa Kolisia B, sebelum proyek air bersihnya rampung pada tahun 2009, sumber air bersih masyarakat berasal dari air irigasi yang melewati desanya. Terdapat hanya kurang dari $40 \%$ anak yang menempati tempat tinggal dengan fasilitas buang air besar, dan umumnya berupa jamban cemplung sederhana. Dibandingkan antar desa, fasilitas jamban di Desa Magepanda dan Kolisia adalah paling baik (Tabel 6). Namun secara keseluruhan angka kepemilikannya masih kurang dari $40 \%$. Hal ini menunjukkan masih terbatasnya sarana kebersihan dan sanitasi di wilayah kecamatan penelitian ini.

Hak Pendidikan, Waktu Luang, dan Kegiatan Budaya. Pendidikan mempunyai peranan penting dan sudah menjadi kebutuhan pokok bagi anak-anak dan dapat digunakan sebagai salah satu indikator untuk mengukur tingkat kesejahteraan anak. Pembangunan di bidang pendidikan memerlukan peran serta aktif tidak saja dari pemerintah, tetapi juga dari masyarakat dan seluruh keluarga. Pembangunan di bidang pendidikan meliputi pendidikan formal maupun nonformal. Sejak tahun 1994, pemerintah telah mencanangkan wajib belajar 9 tahun. Dengan semakin lamanya usia wajib belajar diharapkan tingkat pendidikan anak semakin membaik, dan akan berpengaruh pada tingkat kesejahteraan penduduk.

Anak balita yang mengikuti PAUD hanya sekitar $10 \%$ dari total anak balita di desa penelitian. Sebagian besar ibu menyatakan tidak mengetahui manfaat PAUD dan tidak menemukan perbedaan yang nyata antara anak yang ikut dan tidak ikut PAUD, sehingga PAUD menjadi kurang diminati. Sementara penduduk berumur 7-18 tahun yang tidak/belum pernah sekolah di desa penelitian sebanyak 16,7\%. Angka persentase penduduk yang tidak/belum pernah sekolah relatif berimbang antara laki-laki dan perempuan. Jika dilihat berdasarkan angka partisipasi sekolah (APS) diketahui bahwa terjadi penurunan APS seiring dengan meningkatnya jenjang pendidikan. Sebanyak $54,5 \%$ anak usia 7-18 tahun telah mengenyam pendidikan SD, namun yang

Tabel 6. Sebaran anak berdasarkan fasilitas tempat tinggal

\begin{tabular}{lcccccc}
\hline \multirow{2}{*}{ Fasilitas Tempat Tinggal Anak* } & \multicolumn{7}{c}{ Desa (\%) } \\
\cline { 2 - 6 } & Magepanda & Kolisia b & Kolisia & Done & Reroroja & Total \\
\hline Tersedia sumber air bersih & 99,0 & 98,3 & 97,7 & 94,9 & 93,7 & 96,7 \\
Tersedia tempat buang air besar & 57,3 & 35,1 & 39,9 & 17,7 & 23,0 & 36,7 \\
Tersedia ventilasi yang baik & 46,7 & 75,7 & 53,2 & 24,4 & 40,8 & 46,9 \\
\hline
\end{tabular}

*Total responden: Magepanda 722; Kolisia b 313; Kolisia 547; Done 361; Reroroja 683 
mengenyam pendidikan hingga SMA hanya sekitar $10 \%$. Hal ini menunjukkan tingkat partisipasi dan kesadaran tentang pentingnya pendidikan masih sangat rendah, disamping faktor eksternal seperti tak tersedianya sekolah (SMP maupun SMA) di Kecamatan Magepanda ataupun lokasi terjangkau. Masalah kemiskinan menjadi salah satu penyebab mengingat biaya transportasi ke sekolah pada umumnya relatif tinggi dibandingkan biaya sekolah itu sendiri.

Ditinjau dari alasan anak yang tidak sekolah, terutama karena kurang biaya, dan sarana pendidikan yang kurang memadai. Sarana pendidikan yang terdapat di desa penelitian sebagian besar berupa bangunan SD $(54,6 \%)$, sementara bangunan SMP dan SMA masih sulit ditemukan. Diantara banyaknya anak yang putus sekolah, hanya $1 \%$ yang mengikuti pendidikan alternatif. Sarana pendidikan alternatif yang terdapat di desa penelitian adalah Kejar Paket A $(24,6 \%)$ dan Kejar Paket B (12,4\%) (Tabel 7).

Kegiatan waktu luang dan kegiatan budaya juga dianggap penting pengaruhnya bagi perkembangan anak. Dari data yang ada hanya kegiatan bermain yang dapat mewakili pemenuhan hak waktu luang dan budaya. Pada Tabel 8 tampak bahwa hampir seluruh $(96,8 \%)$ responden menyatakan bahwa anak suka bermain di rumah teman, sementara anak balita cenderung bermain di dalam rumah $(60 \%)$. Tempat bermain anak balita harus terlihat oleh orangtua agar lebih mudah dalam hal pengawasan. Namun demikian secara rata-rata hanya kurang $30 \%$ ibu mengaku bahwa anak balita selalu ditemani saat bermain dan ibu adalah orang yang paling sering menemani anak balita bermain $(58,9 \%)$.

Tabel 7. Sebaran anak berdasarkan hak pendidikan

\begin{tabular}{lcccrrr}
\hline \multirow{2}{*}{ Pendidikan* $^{*}$} & \multicolumn{5}{c}{ Desa (\%) } \\
\cline { 2 - 6 } & Magepanda & Kolisia b & Kolisia & Done & Reroroja & Total \\
\hline Sarana pendidikan yang ada di desa & & & & & \\
PAUD & 80,9 & 12,5 & 65,6 & 22,7 & 20,1 & 45,7 \\
SD & 57,3 & 57,5 & 59,4 & 35,7 & 56,7 & 54,6 \\
Kejar Paket A & 40,7 & 7,3 & 41,7 & 28,0 & 0,1 & 24,6 \\
Kejar Paket B & 43,8 & 1,9 & 0,7 & 0,0 & 0,0 & 12,4 \\
\hline
\end{tabular}

*) Total responden: Magepanda 722; Kolisia b 313; Kolisia 547; Done 361; Reroroja 683

Tabel 8. Sebaran anak berdasarkan hak pemanfaatan waktu luang

\begin{tabular}{|c|c|c|c|c|c|c|}
\hline \multirow{2}{*}{ Pemanfaatan Waktu Luang } & \multicolumn{6}{|c|}{ Desa* $\left.^{*} \%\right)$} \\
\hline & Magepanda & Kolisia b & Kolisia & Done & Reroroja & Total \\
\hline \multicolumn{7}{|l|}{ Tempat bermain anak } \\
\hline Rumah teman & 98,9 & 97,2 & 91,5 & 98,8 & 97,7 & 96,8 \\
\hline Lapangan & 1,1 & 0,7 & 1,9 & 0,6 & 1,7 & 1,3 \\
\hline Hutan & 0,0 & 0,0 & 0,4 & 0,0 & 0,3 & 0,2 \\
\hline Kebun & 0,0 & 2,1 & 0,0 & 0,0 & 0,3 & 0,3 \\
\hline Lainnya & 0,0 & 0,0 & 6,2 & 0,6 & 0,0 & 1,4 \\
\hline \multicolumn{7}{|l|}{ Tempat bermain anak balita } \\
\hline Di rumah & 96,9 & 25,5 & 74,2 & 0,0 & 43,9 & 60,0 \\
\hline Rumah teman & 2,8 & 27,7 & 23,2 & 95,4 & 3,6 & 19,9 \\
\hline Lapangan & 0,0 & 0,0 & 0,5 & 4,6 & 0,0 & 0,6 \\
\hline Kebun & 0,0 & 2,1 & 1,6 & 0,0 & 0,0 & 0,6 \\
\hline Lainnya & 0,4 & 44,7 & 0,5 & 0,0 & 52,5 & 18,9 \\
\hline $\begin{array}{l}\text { Tempat bermain anak balita dapat } \\
\text { dilihat orangtua }\end{array}$ & 36,8 & 39,0 & 38,9 & 25,8 & 38,1 & 36,3 \\
\hline Anak balita ditemani saat bermain & 24,7 & 36,7 & 33,6 & 24,1 & 30,5 & 29,4 \\
\hline \multicolumn{7}{|l|}{ Yang menemani anak balita bermain } \\
\hline Ayah & 13,6 & 4,1 & 35,1 & 4,6 & 2,2 & 13,1 \\
\hline Wali laki-laki & 0,4 & 0,0 & 4,9 & 0,8 & 0,9 & 1,5 \\
\hline Ibu & 49,8 & 47,1 & 55,1 & 51,9 & 82,4 & 58,6 \\
\hline Wali perempuan & 33,0 & 5,0 & 1,5 & 9,2 & 3,5 & 12,6 \\
\hline Kakak besar & 3,2 & 32,2 & 3,4 & 28,2 & 10,6 & 12,0 \\
\hline Lainnya & 0,0 & 11,6 & 0,0 & 5,3 & 0,4 & 2,3 \\
\hline
\end{tabular}

*) Total responden: Magepanda 722; Kolisia b 313; Kolisia 547; Done 361; Reroroja 683 
Anak merupakan sumber potensi serta penerus cita-cita negara, oleh karena itu harus mendapatkan kesempatan besar untuk tumbuh dan berkembang secara optimal. Semakin baik pemenuhan hak anak akan menunjang proses tumbuh kembang anak yang semakin baik pula. Pemenuhan hak anak dalam penelitian ini kemudian dibagi menjadi tiga kategori, yaitu kurang, cukup dan baik. Berdasarkan Gambar 2, lebih dari $50 \%$ responden sudah memenuhi hak anak dengan baik $(51,4 \%)$, dengan skor rata-rata 29,3 (skor total 38). Hasil uji beda terhadap rata-rata skor menunjukkan perbedaan yang nyata antar desa $(p<0,01)$. Namun demikian, masih terdapat beberapa hal yang harus diperbaiki, khusunya menyangkut hak sipil dan kebebasan serta hak memperoleh pendidikan.

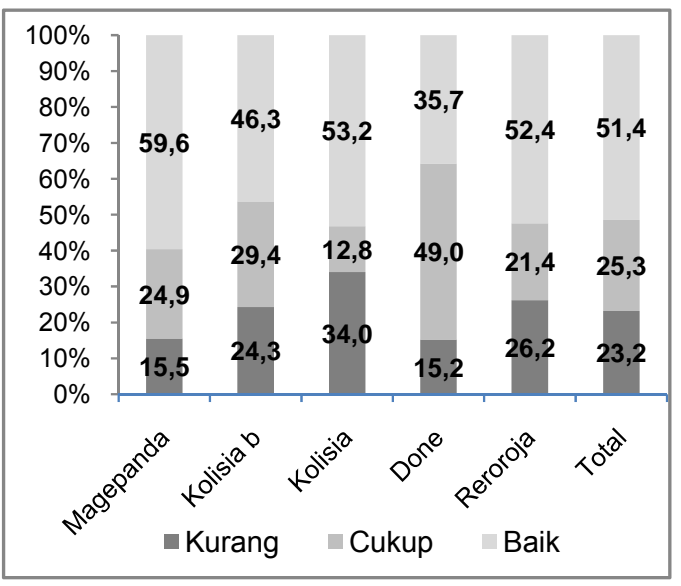

Gambar 2. Sebaran pemenuhan hak anak

\section{Hubungan antara Karakteristik Sosial Ekonomi Rumah Tangga dan Pemenuhan Hak Anak}

Keterpurukan kondisi perekonomian Indonesia tidak saja berpengaruh terhadap para pelaku ekonomi, namun juga memberikan dampak negatif pada sisi kehidupan sosial masyarakat, sampai ke pelosok. Akibatnya banyak rumah tangga yang mengalami kesulitan memenuhi berbagai kebutuhan dasar. Pengaruh kondisi tersebut juga berimbas kepada anak-anak, yaitu tidak dapat melanjutkan sekolah (drop out) atau dengan terpaksa mereka harus bekerja untuk membantu ekonomi rumah tangganya.

Terdapat hubungan yang positif dan nyata antara kondisi sosial ekonomi rumah tangga dan pemenuhan hak anak $(p<0,01)$. Semakin baik kondisi sosial ekonomi ternyata berdampak pada baiknya pemenuhan hak anak oleh keluarga (Tabel 9). Hal ini berarti rumah tangga dengan pendapatan rendah relatif kurang dalam upaya pemenuhan hak anak untuk kebebasan sipil dan pendidikan, demikian pula dalam pemenuhan kesejahteraan. Dari penelitian terdahulu di wilayah Provinsi NTT (Martianto et al. 2007 dan Martianto et al. 2008) terlihat ada hubungan antara pendidikan yang rendah dengan akses keluarga (terutama ibu) pada pelayanan kesehatan dan gizi, demikian pula pada pengetahuan gizi dan kesehatan, sehingga pengasuhan anak menjadi kurang optimal. Selanjutnya pada penelitian ini terlihat bahwa keluarga dengan pendapatan relatif lebih rendah memiliki kemampuan pemenuhan hak anak yang lebih rendah, terkait pemenuhan hak pencatatan kelahiran anak, pendidikan dan kesejahteraan (terutama terkait tempat tinggal yang memadai).

Tabel 9. Sebaran responden berdasarkan karakteristik sosial ekonomi rumah tangga dan pemenuhan hak anak

\begin{tabular}{|c|c|c|c|c|c|c|c|c|c|}
\hline \multirow{3}{*}{$\begin{array}{l}\text { Sosial Ekonomi } \\
\text { Rumah tangga }\end{array}$} & \multicolumn{6}{|c|}{ Pemenuhan Hak Anak } & \multirow{2}{*}{\multicolumn{2}{|c|}{ Total }} & \multirow{3}{*}{$\begin{array}{c}\text { P. } \\
\text { value }\end{array}$} \\
\hline & \multicolumn{2}{|c|}{ Kurang } & \multicolumn{2}{|c|}{ Cukup } & \multicolumn{2}{|c|}{ Baik } & & & \\
\hline & $\mathbf{n}$ & $\%$ & $\mathbf{n}$ & $\%$ & $\mathrm{n}$ & $\%$ & $n$ & $\%$ & \\
\hline Kurang & 608 & 100,0 & 594 & 89,3 & 190 & 14,0 & 1392 & 53,0 & \\
\hline Cukup & 0 & 0,0 & 71 & 10,7 & 582 & 43,0 & 653 & 24,9 & \\
\hline Baik & 0 & 0,0 & 0 & 0,0 & 581 & 42,9 & 581 & 22,1 & 0,000 \\
\hline Total & 608 & 100,0 & 665 & 100,0 & 1353 & 100,0 & 2626 & 100,0 & \\
\hline
\end{tabular}

*hubungan nyata $\alpha=1 \%$ 


\section{KESIMPULAN DAN SARAN}

\section{Kesimpulan}

Separuh responden memiliki situasi sosial ekonomi yang termasuk dalam kategori kurang $(53 \%)$. Sementara lebih dari separuh keluarga sudah memenuhi hak anak dengan baik $(51,4 \%)$. Hasil uji beda terhadap rata-rata skor situasi sosial ekonomi dan pemenuhan hak anak menunjukkan perbedaan yang nyata antar desa $(p<0,01)$.

Terdapat hubungan yang positif dan nyata antara kondisi sosial ekonomi rumah tangga dan pemenuhan hak anak $(p<0,01)$, yaitu keluarga dengan pendapatan yang lebih tinggi lebih dapat melakukan pencatatan kelahiran anak, menyediakan pendidikan dan tempat tinggal yang memadai dibandingkan rumah tangga dengan pendapatan rendah.

\section{Saran}

Mengingat adanya hubungan antara status sosial ekonomi keluarga dengan kemampuan pemenuhan hak anak, maka disarankan agar pemerintah DT II maupun pemerintah tingkat kecamatan dan desa untuk dapat menyediakan program upaya peningkatan fasilitas atau kebijakan terkait pencatatan kelahiran, penyediaan sarana pendidikan serta sarana infrastruktur air bersih dan WC umum. Untuk meningkatkan aspek pastisipasi anak dalam pembangunan berbasis hak anak, disarankan pula agar di seluruh wilayah dampingan PLAN di Kabupaten Sikka dilaksanakan program desa ramah anak, agar proses pembangunan desa senantiasa memperhatikan kepentingan dan hak anak untuk hidup sejahtera. Saat ini baru Desa Magepanda yang sedang diinisiasi untuk menjadi Desa Ramah Anak.

\section{UCAPAN TERIMA KASIH}

1. Pemerintah Desa dan Pemerintah Kecamatan Magepanda untuk kerjasamanya dalam usaha peningkatan pemenuhan hak anak di Kecamatan Magepanda.

2. Sekretaris desa dan Kader Komunikasi Sponsorship yang mengkoordinasi dan melakukan pengumpulan data di lapangan.

3. Semua stakeholder di Kecamatan Magepanda yang memiliki kepedulian terhadap pemenuhan hak anak.

4. Peng-entry data: Ana Alexa, Salves, Ansel, dan Adith Donny yang telah membantu proses survei ini.
5. Teman-teman staf Plan Indonesia Sikka yang turut membantu kelancaran proses survei di lapangan.

\section{DAFTAR PUSTAKA}

[BPS] Badan Pusat Statistik. 2000. Laporan Indikator Kesejahteraan Anak. Jakarta: BPS.

[Depsos] Departemen Sosial. 2000. Profil kesejahteraan dan perlindungan anak. Jakarta: Depsos.

Hastuti D. 1989. Faktor Demografi dan Non Demografi yang mempengaruhi Besar Keluarga dan Status Gizi Anak Balita Keluarga Petani di Desa Neglasari, Kecamatan Ciomas, Kabupaten Bogor [Skripsi]. Jurusan Gizi Masyarakat dan Sumberdaya Keluarga, Fakultas Pertanian, IPB.

Martianto D, Riyadi H, Hastuti D, Alfiasari. 2006. Ketersediaan, Konsumsi Pangan dan Status Gizi Anak Balita di Kabupaten Lembata, Provinsi NTT. Kerjasama Fakultas Ekologi Manusia dengan Plan International Indonesia.

Martianto D, Riyadi H, Hastuti D, Damayanthi E, Murtilaksono K. 2007. Analisis Situasi Ketahanan Pangan dan Gizi dan Program untuk Memperkuat Ketahanan Pangan dan Memperbaiki Status Gizi Anak di Kabupaten Timor Tengah Utara, Provinsi Nusa Tenggara Timur. Kerjasama Fakultas Ekologi Manusia dengan Plan International Indonesia.

Martianto D, Riyadi H, Hastuti D. 2008. Analisis Situasi Ketahanan Pangan dan Gizi dan Program untuk Memperkuat Ketahanan Pangan dan Memperbaiki Status Gizi Anak di Kabupaten Timor Tengah Selatan, Provinsi Nusa Tenggara Timur Kerjasama Fakultas Ekologi Manusia dengan Plan International Indonesia.

Najih M. 2003. Perlindungan hak asasi anak dalam hukum Indonesia. Jurnal Legality, Vol. 11 No. 2 September 2003-Februari 2004. Hal. 263.

[SUSENAS] Survei Sosial Ekonomi Nasional. 2000. Jakarta : BPS.

\footnotetext{
*Korespondensi :

Telp : +62-251 8628303

Email: tutimartianto@yahoo.com
} 